\title{
Michał Klichowski, „Między linearnością a klikaniem. O społecznych konstrukcjach podejść do uczenia się", Wyd. Impuls, Kraków 2012
}

Termin „uczenie się” należy do fundamentalnych pojęć pedagogiki i psychologii. W słownikach językoznawczych definiowany jest jako zdobywanie wiedzy, informacji, czy umiejętności. Nauki społeczne ujmują to pojęcie szerzej, jako wszelkie zmiany w zachowaniu, które można przypisać określonym doświadczeniom z przeszłości. W Polsce definiowanie „uczenia się” osadzone jest nadal w „szkolno-podręcznikowym” kontekście. Postrzega się je jako aktywność zinstytucjonalizowaną, związaną ze szkołą i edukacją formalną. W recenzowanej książce przyjęta została definicja uczenia się J. S. Brunera, który rozumie je jako zmianę potencjału reakcji. Termin „podejście do uczenia się" został zdefiniowany w oparciu o pracę brytyjskiego badacza Paula Ramsdena, zatytułowaną Learning to Teach in Higher Education, w której autor wymienia dwa znaczenia tego terminu. Pierwsze zakłada indywidualny sposób definiowania uczenia się człowieka (subiektywna teoria uczenia się), drugie - indywidualny sposób uczenia się stosowany nieświadomie lub świadomie przez człowieka.

Celem recenzowanej książki jest odpowiedź na pytanie, w jakim stopniu podejścia do uczenia się młodzieży są konstruowane społecznie. Ponadto publikacja ma dać możliwość refleksyjnego odniesienia się do fenomenu podejścia do uczenia się jako konstruktu społecznego oraz namysłu nad temporalnym uwikłaniem sposobów poznawania świata przez człowieka. W książce stawiana jest hipoteza zakładająca, iż w stopniu istotnym podejścia do uczenia się są skonstruowane społecznie. Fenomen podejścia do uczenia się jest więc uzależniony od zachodzących między ludźmi interakcji. Autor postanowił sprawdzić powyższą hipotezę analizując sposoby uczenia 
się młodzieży o odmiennym kapitale kulturowym, rozpatrywanych w kontekście dwóch rywalizujących ze sobą współcześnie kategorii, które symbolicznie zostały nazwane linearnością i klikaniem.

Recenzowana książka została podzielona na dwie części. Pierwsza część to teoretyczne podstawy podejmowanych badań, w której zaprezentowane zostały trzy wybrane perspektywy konstruowania teorii uczenia się: neurobiologiczna (1 rozdział), psychologiczna (2 rozdział) oraz socjologiczna (3 rozdział). W rozdziale pierwszym autor zauważa, że współcześnie obserwujemy zintensyfikowane przenikanie do pedagogiki i psychologii nauk o układzie nerwowym. Odkrycia tych nauk związane z budową i funkcjonowaniem mózgu, miały znaczenie dla przesunięcia w pedagogice zainteresowania z nauczania na proces uczenia się. Można zatem przyjąć, że neurobiologiczna perspektywa oglądu uczenia się dotyczy relacji: funkcjonowanie mózgu - przebieg uczenia się, czyli wyjaśnienia uczenia się na drodze poznania mechanizmów nerwowych. W czterech podrozdziałach składających się na ten rozdział znajdziemy: rys historyczny kształtowania się myśli neurobiologicznej od czasów starożytnych do współczesności, podstawy anatomiczne ludzkiego mózgu w kontekście próby lokalizacji funkcji uczenia się, opis mechanizmów zapamiętywania i przypominania wyuczonych informacji oraz teorię plastyczności mózgu, która jawi się jako neurobiologiczna przesłanka hipotezy zakładającej, że podejścia do uczenia się są społecznymi konstruktami.

W drugim rozdziale, poświęconym perspektywie psychologicznej uczenia się, pojęcie to jest szerzej definiowane i oznacza wszelkie procesy zachodzące w układzie nerwowym prowadzące do zmian w zachowaniu człowieka oraz do nabywania gotowości do przetwarzania odpowiedniego rodzaju informacji w przyszłości.

Uczenie się w perspektywie socjologicznej, ukazane w trzecim rozdziale publikacji, jest procesem, dla którego układem staje się otaczający świat. Oznacza to, że uczenie się jest zakorzenione w kontekstach społecznych, ma konstrukcję historyczno-społeczną. W pierwszym podrozdziale zarysowana została koncepcja społecznego konstruktywizmu będąca bazą prowadzonych rozważań. W kolejnych dwóch podrozdziałach zaprezentowane zostały dwie teorie konfliktu, teoria reprodukcji kulturowej Pierre'a Bourdieu i Jeana-Claude'a Passerona oraz teoria reprodukcji ekonomicznej Samuela Bowlesa i Herberta Gintisa, jako koncepcje konstytuujące, przyjmowane w książce założenia. Ostatni podrozdział traktuje o zwrocie lingwistycznym w dyskursie humanistycznym, który został wykorzystany jako druga matry- 
ca analityczna podejść do uczenia się. Rozdział ten jest raczej refleksją nad poruszaną kwestią niż opisem zastanej wiedzy.

Druga część książki to studium empiryczne. Ukazany tu został metodologiczny kontekst podjętych badań (4 rozdział), dokonano opisowej, tabelarycznej i graficznej prezentacji wyników przeprowadzonych badań (5 i 6 rozdział), a także przedstawiono ich interpretację, podsumowanie i przeprowadzoną dyskusję w obrębie wniosków wyprowadzonych z tych wyników (7 rozdział).

Autor zdecydował się na przyjęcie ilościowej strategii badań. Strategia ta została wzbogacona o analizy jakościowe. W badaniach zastosowano metodę badań quasi-eksperymentalnych. Badacz wykorzystał technikę pomiaru samoregulacji w trakcie uczenia się. Narzędziem tej techniki była autorska aplikacja (komputerowy program użytkowy) rejestru sposobów eksploracji tekstu, nazwana roboczo InteractiveStory-Tracker. Stosowany na potrzeby badań tracker był stroną internetową używaną offline. Składała się ona ze strony startowej, strony głównej, 60 podlinkowanych stron oraz programu rejestrującego sposób eksploracji tekstu, czas fiksacji na każdej odwiedzanej stronie oraz korzystnie z planu tekstu. Badania zostały przeprowadzone w sześciu szkołach, w trzech województwach. Objęte nimi zostały dwie trzydziestosześcioosobowe grupy. Dobór do grup opierał się na klasyfikacji badanych zgodnie z wartością zmiennej niezależnej. Przeprowadzone badania umożliwiły wyprowadzenie konstatacji, iż zróżnicowanie kapitałów kulturowych koreluje ze zróżnicowaniem przejawianych podejść do uczenia się. Osoby o niskim kapitale kulturowym przejawiały w większości podejście do uczenia się z tendencją linearną - nie dostrzegały związków i uwikłań danego problemu oraz preferowały jednowymiarowy, narzucony kontekst uczenia się. Takie podejście może prowadzić do niezrozumienia otaczającego świata i miotania się w zawiłościach życia społecznego. Osoby o wysokim kapitale kulturowym przejawiały natomiast najczęściej podejście do uczenia się z tendencją klikaną - zatapiały się w nowościach, uczyły się ciągle czegoś nowego, nie kończąc procesu uczenia się poprzedniego. Takie podejście jest pewną reprezentacją współczesnej potrzeby zmiany i szybkości.

Recenzowana publikacja ma dużą wartość merytoryczną. Na uwagę zasługuje starannie opisana droga postępowania badawczego, począwszy od problematyki metodologicznej, po przedstawienie materiału badawczego, aż po jego dokładną i wnikliwą analizę. Część empiryczna bogata jest w tabele, wykresy i diagramy, które w przejrzysty sposób prezentują wyniki badań. 